\title{
Budget impact model for oncopharmacogenetics from the perspective of mandatory basic health insurance in Switzerland using the example of breast cancer
}

Thomas D Szucs'

Kevin P Szillat ${ }^{2}$

Eva Blozik ${ }^{3}$

'University of Basel, Institute of Pharmaceutical Medicine (ECPM), Basel, Switzerland; ${ }^{2}$ Department of Biology, Institute of Molecular Health Sciences, ETH Zurich, Zürich, Switzerland; ${ }^{3}$ Department of Health Sciences, Helsana Group, Zürich, Switzerland
Correspondence: Eva Blozik

Department of Health Sciences, Helsana Group, Post Box, CH-808I Zürich, Switzerland

Tel +4I 583407101

Fax +4I 583400306

Email eva.blozik@helsana.ch
This article was published in the following Dove Press journal:

Pharmacogenomics and Personalized Medicine

\begin{abstract}
Single-nucleotide polymorphisms (SNPs) can severely impact individual drug response and health outcomes in cancer patients. Genetic tests to screen for marker SNPs are available to adjust the drug dose of oncologicals to the patient's needs. However, it is unclear whether the positive effects outbalance the increased costs or even lead to an overall cost reduction. This very pragmatic analysis used three frequently used oncologicals for the treatment of breast cancer to evaluate whether preemptive pharmacogenetic testing may have a cost-reducing impact on health care spending in the Swiss health care system. Our results indicate that oncopharmacogenetics might help to reduce health care costs (ie, by avoiding adverse drug effects) and to increase efficiency of drugs in oncologic patients.
\end{abstract}

Keywords: pharmacogenetics, oncology, budget impact model, Switzerland, health insurance

\section{Introduction}

Single-nucleotide polymorphisms (SNPs) can severely impact individual drug response and health outcomes in oncologic patients. Genetic tests to screen for marker SNPs are available to adjust the drug dose of oncologicals to the patient's needs, and this information - as opposed to dynamic plasma measurements - does not change over time. ${ }^{1,2}$ However, it is unclear whether the positive effects outbalance the increased costs or even lead to an overall cost reduction. ${ }^{3}$

The aim of this very pragmatic analysis is to give a crude but illustrative first idea of whether preemptive pharmacogenetics testing may have a cost-reducing impact on health care spending related to cancer drugs in the Swiss health care system. We therefore used the example of three frequently used oncologicals for the treatment of breast cancer (tamoxifen, capecitabin, and lapatinib). The Swiss National Institute for Cancer Epidemiology reported 76,489 prevalent and 4,733 incident cases of female breast cancer in Switzerland in $2015 .^{4}$

\section{Methods}

To estimate drug costs and use of these drugs, we analyzed real-life drug reimbursement data of one of the largest Swiss basic mandatory health insurances, including persons from all parts of the country (10,794 persons with tamoxifen, 3,022 persons with capecitabin, and 10 persons with lapatinib). For each of these cancer drugs, the share of breast cancer patients treated with these drugs was calculated by dividing 
Table I Active components and share of patients treated

\begin{tabular}{ll}
\hline Active component & Share of patients treated (\%) \\
\hline Tamoxifen & 14.11 \\
Capecitabin & 3.95 \\
Lapatinib & 0.01 \\
\hline
\end{tabular}

Table 2 Results of the budget impact of model by active components with the corresponding genes

\begin{tabular}{|c|c|c|c|c|c|c|c|c|}
\hline Oncological & Gene & $\begin{array}{l}\text { Prevalence } \\
\text { of gene }\end{array}$ & $\begin{array}{l}\text { Sales volume } \\
\text { of drug } \\
(\mathrm{CHF})\end{array}$ & $\begin{array}{l}\text { Patient } \\
\text { population } \\
\text { treated with } \\
\text { drug and } \\
\text { presenting with } \\
\text { corresponding } \\
\text { gene (population } \\
\text { at risk) (N) }\end{array}$ & $\begin{array}{l}\text { Costs } \\
\text { of test } \\
(\mathrm{CHF})\end{array}$ & $\begin{array}{l}\text { Number of new } \\
\text { cases who get } \\
\text { treated with } \\
\text { the drug and } \\
\text { therefore need } \\
\text { to get tested } \\
\text { per year }(\mathrm{N})^{\mathrm{a}}\end{array}$ & $\begin{array}{l}\text { Costs for } \\
\text { patient } \\
\text { population } \\
\text { at risk } \\
(\mathrm{CHF})^{\mathrm{a}}\end{array}$ & $\begin{array}{l}\text { Difference } \\
\text { between annual } \\
\text { drug costs in } \\
\text { population at } \\
\text { potential risk } \\
\text { and expected } \\
\text { annual costs for } \\
\text { genotyping (CHF) }\end{array}$ \\
\hline Tamoxifen & $C Y 2 D 6$ & 0.47 & $2,051,099$ & 5,074 & 333 & 668 & 964,016 & 741,583 \\
\hline Capecitabin & DPYD & 0.04 & $4,427,049$ & 121 & 198 & 187 & 177,082 & 140,074 \\
\hline Lapatinib & HLA & 0.25 & 102,274 & 3 & 238 & 0,62 & 25,569 & 25,422 \\
\hline
\end{tabular}

Note: ${ }^{\text {TThis }}$ was calculated by multiplying the drug sales volume with the prevalence of the correlating gene.

the prevalence of breast cancer by the number of persons receiving the corresponding drug in health insurance claims, projected to the total population of Switzerland (Table 1).

For each drug, the sales volume for the patient population presenting with the correlating gene was calculated, based on the prevalence of genes taken from the literature. ${ }^{5}$ Genotyping costs were requested from Swiss or international companies. Currency exchanges were made based on the current currency exchange rate, which was $1 \mathrm{USD}=0.9895 \mathrm{CHF}$.

\section{Results}

Table 2 shows a broad variability of the difference between annual test costs for genotyping in all incident cases and the costs for treatment in patients with the corresponding gene. The more positive the difference, the higher the likelihood of oncopharmacogenetic testing to be cost effective. If drug treatment costs for patients do not exceed that difference, oncopharmacogenetic testing will be cost saving. However, it is very likely that dose modifications based on oncopharmacogenetic test results avoid adverse events, which leads to additional significant savings. The more adverse events can be avoided, the higher the likelihood for cost effectiveness of oncopharmacogenetic testing.

\section{Discussion}

The present pragmatic analysis indicates that oncopharmacogenetic testing might help to reduce health care costs and to increase efficiency of drugs in oncologic patients. More specifically, the present study supports the demand for more detailed studies using properly defined populations, and based on a rigorous scientific protocol, to evaluate potential positive effects on patient-relevant outcomes, potential risks, and costs in a highly dynamic system. However, in addition to developing new active components, it might be just as important to use already existing drugs in a more efficient manner.

\section{Disclosure}

The authors report no conflicts of interest in this work.

\section{References}

1. Ciriello G, Miller ML, Aksoy BA, Senbabaoglu Y, Schultz N, Sander C. Emerging landscape of oncogenic signatures across human cancers. Nat Genet. 2013;45(10):1127-1133.

2. Pesenti C, Gusella M, Sirchia SM, Miozzo M. Germline oncopharmacogenetics, a promising field in cancer therapy. Cell Oncol (Dordr). 2015;38(1):65-89.

3. Prudkin L, Nuciforo P. Obstacles to precision oncology: confronting current factors affecting the successful introduction of biomarkers to the clinic. Cell Oncol (Dordr). 2015;38(1):39-48.

4. National Institute for Cancer Epidemiology and Registration (NICER) [webpage on the Internet]. Statistics. Available from: http://www.nicer. org/en/statistics-atlas/. Accessed October 16, 2017.

5. National Human Genome Research Institute, National Institutes of Health [webpage on the Internet]. About the International HapMap Project. Available from: https://www.genome.gov/11511175/ about-the-international-hapmap-project-factsheet/. Accessed May 26, 2016. 
Pharmacogenomics and Personalized Medicine is an international, peerreviewed, open access journal characterizing the influence of genotype on pharmacology leading to the development of personalized treatment programs and individualized drug selection for improved safety, efficacy and sustainability. This journal is indexed on the American Chemical
Society's Chemical Abstracts Service (CAS). The manuscript management system is completely online and includes a very quick and fair peer-review system, which is all easy to use. Visit http://www.dovepress. com/testimonials.php to read real quotes from published authors.

Submit your manuscript here: https://www.dovepress.com/pharmacogenomics-and-personalized-medicine-journal 